\title{
Water Use Challenges to Oil and Gas Developments
}

\author{
WALly BRAUl, MiKe THEROUX, \\ AND ROBBIE ARMFIELD*
}

As public concern over fracking gains increased prominence in the media, litigation concerning the practice is starting to appear before Canadian courts. The litigation thus far has focused largely on water use and its associated licensing regimes, as well as Aboriginal treaty rights. Opponents of fracking have employed diverse strategies to combat the practice. Aside from the Environmental Appeal Board case involving the Fort Nelson First Nation, the British Columbia government and Nexen, no single strategy has proved particularly successful, though the litigation remains in its infancy. This article profiles the emerging Canadian litigation, considering it alongside the developing American civil litigation.

\section{TABLE OF CONTENTS}

I. INTRODUCTION . . . . . . . . . . . . . . . . . . . . . . . . . . . 324

A. Purpose of this ARTIClE . . . . . . . . . . . . . . . . . . . 324

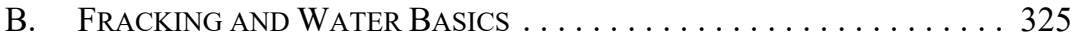

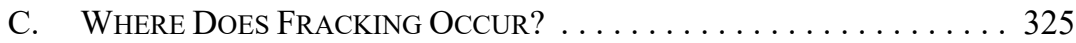

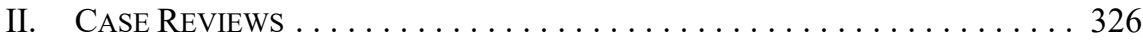

A. APPEALS AND JUdicial REVIEWS OF
WATER LICENCES AND APPROVALS $\ldots \ldots \ldots \ldots \ldots \ldots \ldots \ldots \ldots 26$

B. Challenges to Dispositions OF

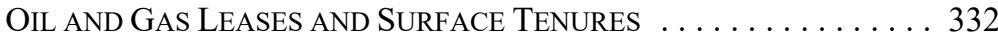

C. ROADBLOCKS AND CIVIL DISOBEDIENCE . . . . . . . . . . . . . . . . . . 334

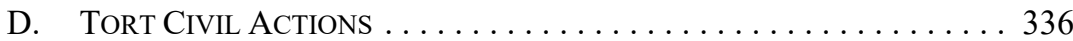

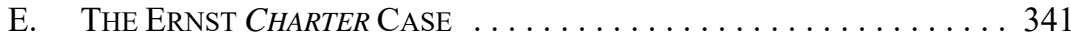

F. Prosecutions . . . . . . . . . . . . . . . . . . . . . . . . 342

III. FutURE DiREction OF WATER-RELATED LitigAtion . . . . . . . . . . . 342

A. InFLUENCE of TSILHQOT'IN NATION V. BRITISH COLUMBiA . . . . . . 342

B. Cumulative EfFects - The Blueberry Civil Action . . . . . . 344

C. The Water Sustainability Act (British Columbia) . . . . . . . 344

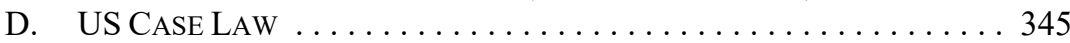

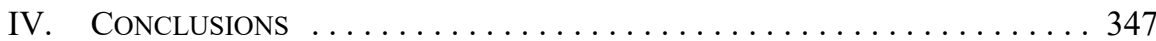

Wally Braul is a regulatory partner at Gowlings LLP, his practice focuses on Aboriginal, environmental, and energy law. Michael Theroux is a litigation partner with Bennett Jones LLP whose practice is focused on energy industry disputes. Robbie Armfield, legal counsel at Nexen Energy ULC, practices regulatory and aboriginal law. 


\section{INTRODUCTION}

\section{A. Purpose of this Article}

Concerns over water use in the oil and gas industry increasingly attract media attention in Canada, echoing the hotly contested debate in the United States. ${ }^{1}$ These concerns tend to focus on water use in hydraulic fracturing ("fracking"), a technology for producing oil and gas. Critics argue, for example, that the huge volume of water needed for fracking severely limits potable water supplies, destroys fish and wildlife habitats, and contaminates local bodies of water. As in the US, water and fracking issues are starting to make their way into Canadian litigation.

This article profiles the emerging Canadian litigation. It describes seven strategies used in decided and pending Canadian cases:

- $\quad$ tribunal appeals and judicial reviews brought by Aboriginal and environmental groups respecting surface water withdrawals destined for fracking;

- judicial reviews brought by Aboriginal groups challenging the Crown's disposition of oil and gas properties that may ultimately be subject to fracking;

- roadblocks by Aboriginal and environmental activists and related injunction proceedings;

- $\quad$ tort claims for civil damages allegedly attributable to fracking;

- $\quad$ a Canadian Charter of Rights and Freedoms ${ }^{2}$ challenge respecting government disclosure of information about fracking impacts;

- a prosecution brought by British Columbia against Nexen, alleging unlawful withdrawals of water destined for fracking operations; and

- a civil action brought by an Aboriginal group — the Blueberry River First Nations of northeastern British Columbia — seeking damages and other remedies for cumulative adverse effects of industrial activities, including fracking, on Treaty 8 rights.

As background, Parts I.B and I.C below describe fracking and when it is used in Canada.

Kevin Bissett, “Anti-fracking protests shouldn't hinder shale-gas sector, NB Energy Minister says," Globe and Mail (14 November 2013), online: <www.theglobeandmail.com/news/politics/anti-frackingprotests-shouldnt-hinder-shale-gas-sector-nb-energy-minister-says/article15447462>; "Police arrest 40 at New Brunswick fracking protest," Toronto Star (17 October 2013), online: <www.thestar.com/news/ canada/2013/10/17/police arrest pepper spray nb fracking protesters first nation official_says.html>; Ayesha Rasscoe, “'̄Anti-fracking protesters arrested in US capital," 2014), online: <www.reuters.com/article/2014/07/14/us-usa-lng-protests-idUSKBN0FJ2F720140714>.

2 Part I of the Constitution Act, 1982, being Schedule B to the Canada Act 1982 (UK), 1982, c 11 [Charter]. 


\section{B. FraCkING AND WATER BASICS}

Fracking is a technology designed to fracture target formations to release gas or oil bound within shale and other sedimentary formations. Fracking first requires vertical drilling to a target formation and then horizontal drilling within that formation. At the subsequent "completion" stage, large volumes of highly pressurized water, chemicals, and proppants (sand) are then injected into the wells to fracture the target formation. The released natural gas or oil then travels via horizontal and vertical wells to the surface, where it is processed, stored, and transported. This increasingly used technology provides an alternative to conventional operations which target (increasingly scarce) pools of oil or gas trapped below a sealing caprock without fracturing those formations. ${ }^{3}$

In common parlance, the term fracking means more than the fracturing of rock. It implies a wide array of activities which support the fracturing process. As discussed below, it is these ancillary activities — many involving water use - which tend to attract litigation. Ancillary activities include:

- $\quad$ acquisition - usually from the Crown but also, in limited cases, from private landowners - of subsurface oil and gas rights tied to certain formations;

- acquisition of surface Crown lands or private lands, where such access is necessary for exploiting the subsurface oil and gas rights;

- $\quad$ exploratory seismic testing of geological formations;

- $\quad$ procuring local surface and groundwater to construct roads, pipelines, and other infrastructure; and

- disposal of so-called "produced water" (a byproduct that migrates to the surface with released gas and oil), whether by recycling it in a fracking operation, trucking it to a treatment facility, or disposal into a deep injection well.

\section{Where Does Fracking OCCUR?}

Fracking technology is most commonly used in Canada in two areas: the Montney Basin, ${ }^{4}$ which extends from northeastern British Columbia to southern Alberta, and the Horn River Basin, ${ }^{5}$ which is found in northeastern British Columbia and the southern portions of the Yukon and the Northwest Territories. Fracking has also recently been used to exploit the

3 Alberta Energy, “Oilfield Glossary: Shale Gas," online: <www.energy.alberta.ca/NaturalGas/944.asp>. See also Oilfield Glossary, sub verbo "conventional reservoir," online: Schlumberger < www.glossary. oilfield.slb.com/en/Terms/c/conventional_reservoir.aspx>; Alberta Energy Regulator, "What is Unconventional Oil and Gas?," online: ‘https://www.aer.ca/about-aer/spotlight-on/unconventionalregulatory-framework/what-is-unconventional-oil-and-gas $>$.

4 Canadian Association of Petroleum Producers, Canada's Natural Gas: Economic Benefits, online: $<$ www.canadasnaturalgas.ca/economic-benefits $>$. Estimates of its natural gas reserves range from 77 trillion cubic feet (tcf) to 166 tcf, ranking in size amongst the larger US shale gas plays.

Ibid. The Horn River Basin alone is estimated to hold between 61 tcf and 96 tcf of natural gas, with annual production estimated at between 1.5 billion cubic feet per day (bcf/d) and $2.5 \mathrm{bcf} / \mathrm{d}$ by 2020 . 
Bakken Formation, ${ }^{6}$ which underlies large areas of northwestern North Dakota, northeastern Montana, southwestern Alberta, southern Saskatchewan, and southwestern Manitoba.

Four other largely undeveloped shale gas formations appear to be of interest to oil and gas producers and likely would be conducive to fracking. These include the Utica Shale in Quebec, the Horton Bluff Group straddling New Brunswick and Nova Scotia, and the Mackenzie Delta and Canol Shale areas in the Northwest Territories.

\title{
II. CASE Reviews
}

\section{A. APPEALS AND JUdicial ReVIEWS OF WATER LICENCES AND APPROVALS}

\author{
1. FORT NELSON FIRST NATION \\ V. BRITISH COLUMBIA (2013-2015) ${ }^{7}$
}

The British Columbia Environmental Appeal Board (EAB) case in FNFN v. BC had its genesis in 2009, when Nexen applied for a water licence to withdraw water from North Tsea Lake to service its fracking operations in the Horn River Basin (Licence). The Crown, represented by the regional water manger (Manager) ${ }^{8}$ at the Ministry of Forests, Lands and Natural Resource Operations (FLNRO), issued the Licence in May 2012 after three years of review, determining that the proposed withdrawals would not have an appreciable adverse effect on the environment or on local First Nations' Treaty 8 rights. ${ }^{9}$

The Fort Nelson First Nation (FNFN) appealed the Licence to the EAB shortly after it was issued, seeking suspension or rescission of the Licence. The appeal reflects the FNFN's longstanding concern about large-scale water withdrawals for industrial development in its traditional territory. ${ }^{10}$

The appeal comprises three decisions: two preliminary decisions in late 2012 and a decision on the merits released on 3 September 2015. The latter decision was based on a 22day hearing which considered wide-ranging expert and lay witness testimony and voluminous documentation. While focused on water issues, the hearing has arguably been

Melanie Bickford, "The Bakken Formation — Our Modern Day Gold Rush," Oil and Gas Magazine (4 April 2013), online: <www.theogm.com/2013/04/04/the-bakken-formation-our-modern-day-gold-rush $>$. This dispute involves three separate decisions referred to collectively as "FNFN v British Columbia" $[F N F N \vee B C]$ and is comprised of the following decisions: Dickie $v$ British Columbia (Assistant Regional Water Manager) (6 November 2012), 2012-WAT-013(a), online: EAB < www.eab.gov.bc.ca/ water/2012wat013a.pdf> [FNFN No 1]; Dickiev British Columbia (Assistant Regional Water Manager) (2012), 73 CELR (3d) 229 (EAB) [FNFN No 2]; Gale v British Columbia (Assistant Regional Water Manager) (3 September 2015), 2012-WAT-013(c), online: EAB <www.eab.gov.bc.ca/water/2012wat 013c.pdf $>$ [FNFN No 3].

$8 \quad$ See Water Act, RSBC (1996), c 483, s 1. The Manager is vested to issue licences under ibid, s 7. Signed in 1899, Treaty 8 encompasses all of northeastern BC, including the Horn River Basin, and large portions of northern Alberta, northwestern Saskatchewan, and the southern portion of the Northwest Territories: see Indian and Northern Affairs Canada, Treaty Research Report: Treaty Eight (1899), by Dennis FK Madill (Ottawa: INAC, 1986).

10 See e.g. Union of BC Indian Chiefs, News Release, "Fort Nelson Nation: Stop wholesale giveaway of water to shale gas industry or face legal challenges" (13 November 2012), online: <www.ubcic.bc.ca/ News_Releases/UBCICNews11131202.html\#axzznv5Eh3gk>. 
the most intensive examination of fracking in Canada. The 3 September 2015 decision has many significant implications for water use and fracking. These decisions are discussed below.

\section{a. The Two Preliminary Decisions}

The first preliminary decision ${ }^{11}$ addresses an issue commonly raised in EAB proceedings, namely whether the decision under appeal should be stayed, given that the time required by the EAB to consider highly factual de novo appeals may take many months (or, as in this case, some 20 months). The FNFN argued that a stay should be granted because of the likelihood of irreparable harm to FNFN's treaty rights and to the prospects of reconciliation with the Crown. Nexen and the Crown submitted that the FNFN's assertions regarding the adequacy of consultation and the potential impact of the Licence on the First Nation's treaty rights could not be properly decided in a stay application procedure and should be determined in the hearing on the merits. Nexen also argued it would suffer significant inconvenience and financial harm if a stay was granted. ${ }^{12}$ The EAB denied the stay application, agreeing with the Crown's and Nexen's arguments.

The second preliminary decision ${ }^{13}$ was a response to the Crown's challenge of the First Nation's standing to appeal the Licence. The Crown argued that the FNFN did not meet the Water Act section 92 standing test for bringing an appeal, specifically because the FNFN was neither an "owner whose land is or is likely to be physically affected by the order" nor a "riparian owner" of the subject waters. ${ }^{14}$ The EAB dismissed the Crown's application, finding that the FNFN was an "owner" because Treaty 8 confirmed rights of possession on Crown land; that is, ownership under the Act is not limited to fee simple or other proprietary ownership rights to exclude others from the land. ${ }^{15}$

\section{b. Key Issues in the Decision of Merits}

The EAB rescinded the Licence effective on the date of the decision (3 September 2015). ${ }^{16}$ The EAB found two fatal flaws respecting the Licence and ruled on many other issues which were not necessarily determinative of the outcome. Collectively, the decision provides numerous practical lessons for the Crown, industry, and Aboriginal groups. The key findings are discussed below.

\section{FNFN No 2, supra note 7.}

Ibid at para 35 .

FNFN No 1, supra note 7.

Ibid at para 26. Pursuant to s 92(1) of the Water Act, supra note 8, both " (b) owner whose land is or is likely to be physically affected by the order, or ... a ... riparian owner ... who considers that their rights are or will be prejudiced by the order" may appeal a decision to the EAB.

15 FNFN No 1, ibid at para 100. The Water Act, ibid, s 1, defines "owner" to include both "a person entitled to possession of any land" and "a person who has a substantial interest in the land." This definition is continued in British Columbia's Bill 18, Water Sustainability Act, 2nd Sess, 40th Leg, British Columbia, 2014 (assented to 29 May 2014) SBC 2014, c15 (not yet in force) [WSA]. The EAB held that the FNFN did not qualify for standing under the "riparian owner" test. 


\section{i. The Flawed Technical Methodology}

Immediately prior to receiving its Licence in early 2012, Nexen withdrew substantial volumes of water from the Tsea watershed to service its fracking operations under two consecutive one-year "approvals" issued pursuant to section 8 of the Water Act. Rather than continue to rely on consecutive one-year approvals, Nexen sought a longer (five-year) term licence.

Nexen's Licence and its supporting Water Development Management Plan were designed to address the data-sparse nature of the shallow Tsea watershed. Unlike other water licences and approvals, the Licence regime used "adaptive management" ${ }^{\prime 17}$ which, for example, called for intensive monitoring of water flows and withdrawals, prescribed water withdrawals attuned to hourly water variations, required ongoing studies of possible effects on habitat, and imposed annual reviews to revisit and adapt withdrawal parameters. ${ }^{18}$ The EAB described the Licence regime as "novel"19 and stated that "Nexen's section 8 approvals imposed far less onerous requirements than the Licence." 20

The EAB nonetheless agreed with the FNFN that the methodologies underpinning the Licence were fatally flawed (particularly due to misuse of hydrometric models and inadequate environmental impact assessments). ${ }^{21}$ The EAB frequently emphasized the need for a highly risk-averse approach in the data-sparse Tsea watershed. ${ }^{22}$ The EAB's focus on risk contrasts with the absence in the decision of a single cited instance of environmental harm (after reviewing 2012 and 2013 withdrawals under the Licence, including two months when Nexen allegedly exceeded withdrawal limits).

\section{ii. The Flawed Consultations}

The Crown's review of the Licence application and associated consultations took 3 years. The EAB found that, from 2009 to 2011 , the Crown was "genuinely willing" to consult with the FNFN, albeit in a way that was "not perfect." ${ }^{\text {"23 }}$ The EAB stated, for example, that the Crown should have as a preliminary matter consulted with the FNFN to "discuss the process itself." ${ }^{24}$ Moreover, once the review process unfolded, it lacked transparency over the respective roles of the Crown, Nexen, and the FNFN. ${ }^{25}$ The Crown was further criticized for untimely updates and "mixed messages." 26

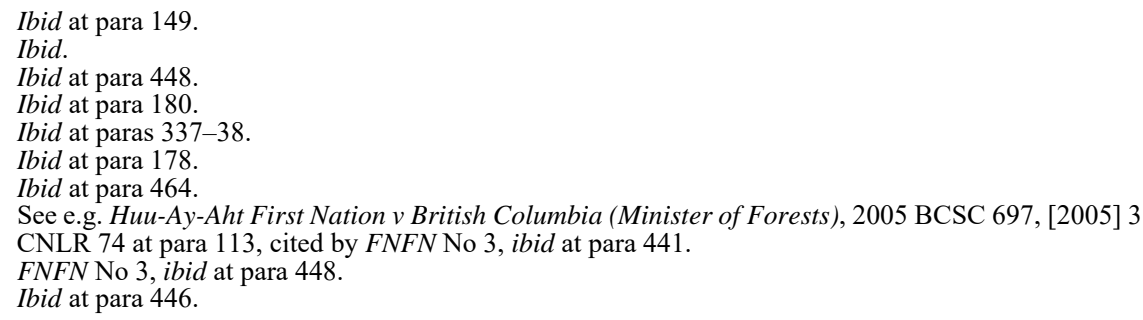


These pre-2012 concerns were mitigated by the fact that the FNFN had failed to adequately disclose its concerns to the Crown. ${ }^{27}$ This failure, the EAB stated, compromised the Crown's ability to consult over the proposed licence. It can be reasonably inferred from the decision that the consultations would have been deemed adequate to the end of 2011 .

In early 2012, shortly before the Licence was issued, the Crown's conduct appeared to change to one lacking in good faith. The EAB's criticism was blunt:

The Panel finds that the Crown failed to consult with the First Nation in good faith. Based on the internal Ministry correspondence and the Manager's rationale, the Panel finds that by April 2012, the Manager intended to issue the Licence regardless of the promised meetings, and had no intention to substantially address any further concerns or information that may have been provided by the First Nation. The Panel finds that this conduct was inconsistent with the honour of the Crown and the overall objective of reconciliation. $^{28}$

\section{iii. Ancillary Issues}

The EAB made numerous findings that did not necessarily affect the outcome of the appeal. These ancillary findings, however, have considerable practical relevance for informing future Crown, Aboriginal, and industry strategies (potentially moreso than the two key findings discussed above):

- Delegating Consultation to a Proponent. Not unlike other project reviews, both Nexen and the Crown contemplated that the former engage regularly with the FNFN and that these discussions would constitute delegated consultation. The Crown's heavy reliance on the discussions between Nexen and the FNFN was, however, criticized by the EAB, stating that, "[f]rom the First Nation's perspective, Nexen may have been involved in consultation simply in furtherance of Nexen's interests, rather than because Nexen was a delegate of the Crown." ${ }^{29}$ The EAB went on to say that, "[a]lthough a consultation agreement is not a prerequisite for consultation, such an agreement would have helped each party to understand the other parties' needs and expectations." ${ }^{30}$

- Cumulative Effects. The FNFN argued that the Crown's consultation should go beyond the proposed withdrawals and consider how the myriad of existing and proposed oil and gas activities in Northeast BC cumulatively affect treaty rights to hunt, fish, and trap. ${ }^{31}$ The EAB agreed with Crown and Nexen arguments that the Water Act did not authorize such a broad scope of impact assessment. ${ }^{32}$

Ibid at paras 455-67.

Ibid at para 484 [emphasis added].

Ibid at para 447.

Ibid at para 442 .

Ibid at para 381 .

Ibid at paras 168-70. 
- The Precautionary Principle: The FNFN argued that the scientifically sound application of the Water Act should comply with the "precautionary principle." 33 Essentially, the precautionary principle (originating in the UN Rio Declaration ${ }^{34}$ ) would put the legal onus on Nexen and the Crown to demonstrate that the proposed withdrawals would not be harmful. ${ }^{35}$ In other words, the onus would shift from the appellant FNFN (to prove a serious concern) to the respondents, Nexen and the Crown, to disprove potential harm. The EAB rejected the FNFN argument, holding that the Water Act was not intended to apply the precautionary principle. ${ }^{36}$

- Scoping Treaty Rights: The EAB acknowledged that the Crown was "generally aware" that the First Nation holds treaty rights in the Tsea area, but failed to identify "exactly where, when or how the First Nation's members exercise treaty rights." 37 The EAB further suggested that the Crown should have considered "which species of fish, animals or plants are used" by the FNFN. ${ }^{38}$ In short, the EAB contemplated a comprehensive research project as a first step in scoping potentially affected treaty rights and commensurate consultation. The EAB criticized the FNFN for not providing the Crown with information in its possession, ${ }^{39}$ but this apparently did not diminish the Crown's challenging task of compiling a comprehensive database. This high onus is arguably not reflected in the case law. For example, the British Columbia Supreme Court in Louis v. British Columbia (Minister of Energy, Mines, and Petroleum Resources) upheld the Crown's preliminary assessment of the First Nation's strength of claim as a basis for scoping the duty to consult, noting as well that the Aboriginal group's "complaints of a very general nature" did not assist the Crown's assessment. ${ }^{40}$ The Crown's preliminary assessment in that case apparently did not entail the comprehensive site-specific research called for by the EAB in FNFN No 3. While the Crown's scoping exercises are fact-driven on a case-by-case basis, the EAB's seemingly high onus leaves uncertainty as to whether the Crown should conduct a comprehensive site-specific — as opposed to a "preliminary" — assessment to identify Aboriginal land use as the basis for scoping relevant treaty rights.

- Environmental Assessment: A central issue in the hearing concerned the degree of scrutiny that should be applied to review potential environmental impacts. The EAB agreed with the FNFN that a much deeper form of impact assessment should have been conducted prior to the issuance of the Licence. Indeed, the EAB set out a long list of environmental baseline and impact assessment studies that should have been required and completed prior to the issuance of the Licence. ${ }^{41}$ The Crown

Ibid at para 179 .

See Report of the United Nations Conference on Environment and Development, GA, 47th Sess, UN Doc A/Conf.151/26 (1992), online: <www.un.org/documents/ga/conf151/aconf15126-1annex1.htm> [UN Rio Declaration].

FNFN No 3, supra note 7 at para 179.

Ibid.

Ibid at para 450 .

Ibid.

Ibid at para 452.

2011 BCSC 1070, 338 DLR (4th) 658 at paras 199-200, aff'd 2013 BCCA 412, 49 BCLR (5th) 302.

See FNFN No 3, supra note 7 at paras 322, 327, 332. 
and Nexen argued that such studies should be required only if the project was "reviewable" under the British Columbia Environmental Assessment Act, ${ }^{42}$ which was not the case here. ${ }^{43}$ These arguments were not addressed directly by the EAB. Rather, the EAB relied on section 10(1)(c) of the Water Act. ${ }^{44}$ This provision, which enables the Crown to require "information" from applicants, was liberally interpreted to mean that the Crown had discretion to require detailed benchmark and environmental impact studies (and, as found by the EAB, should have been so exercised). ${ }^{45}$ The EAB's reasoning may leave future licence applicants uncertain as to whether, after filing an application, they face a lengthy and costly requirement to conduct an environmental assessment not otherwise required under the Environmental Assessment Act.

- Costs: The FNFN asked for costs (unsurprisingly, given its heavy investment in retaining lawyers and experts for the extended hearing). The EAB dismissed the FNFN request. ${ }^{46}$ In doing so, the EAB noted several factors, one of which was the FNFN failure to disclose information that would have assisted the Crown. ${ }^{47}$

\section{WESTERN CANADA WILDERNESS COMMITTEE V. BRITISH COLUMBIA (OIL AND GAS COMMISSION) ${ }^{48}$}

In Wilderness Committee, the core issue was whether the regulator under section 8 of the Water Act may issue consecutive short-term (two-year) approvals to energy companies. ${ }^{49}$ In that case, two environmental non-governmental organizations, Western Canada Wilderness Committee and the Sierra Club of British Columbia Foundation, applied for judicial review by the BC Supreme Court of a decision by the Oil and Gas Commission (OGC) to grant consecutive approvals to Encana.

By way of context, Encana and many other producers in British Columbia rely heavily on section 8 short-term approvals, whether for exploration, potable water for work camps, road construction, or (often most importantly) fracking operations. As a matter of practice, the OGC frequently issues approvals consecutively and for the same body of water. The environmental groups argued that this OGC practice is a de facto long-term disposition of water rights not intended by the Legislature. Long term water rights, the environmental groups argued, should be the subject of licences (and the relevant higher degree of scrutiny required of that instrument as approved to a section 8 approval). ${ }^{50}$

SBC 2002, c 43.

FNFN No 3, supra note 7 at para 152.

Supra note 8, s 10(1)(c).

FNFN No 3, supra note 7 at paras 181-83.

Ibid at para 501 .

Ibid at para 500 .

2014 BCSC 1919, 73 BCLR (5th) 21 [Wilderness Committee].

Ibid at para 3 .

Ibid at para 139. 
The Court found that, whether assessed on a standard of review of reasonableness or on the stricter standard of correctness, the OGC's application of section 8 of the Water Act was proper. ${ }^{51}$ After reviewing the history of the section and the relevant Hansard debates, the Court held that there is nothing in the Water Act that prohibits consecutive approvals for short-term water use. ${ }^{52}$

The Court clarified that a fresh application is required for each consecutive two-year term, following the expiration of an existing section 8 approval: that is, holders of section 8 approvals are not "grandfathered" in. The Court held that all applications (whether original or subsequent) should be "subject to the same rigorous application process." was applied to the Encana approvals. The Court endorsed the OGC policy of applying the following factors to all section 8 applications (whether original or subsequent):

- water flow, availability, and levels specific to the applicable water source;

- $\quad$ OGC discretion to direct lower withdrawals in light of local water availability;

- $\quad$ consideration of other users of the proposed water sources, such as other licencees or approval holders using the same water source or diversion point;

- $\quad$ assessment of wildlife habitat features, potential impact on the habitat, and mitigation strategies; and

- the length of time proposed for water use. ${ }^{54}$

\section{B. Challenges to Dispositions OF \\ OIL AND Gas Leases AND Surface TenuReS}

A second litigation strategy consists of challenging Crown dispositions of oil and gas rights and tenures that could ultimately be used for fracking. This strategy is especially relevant in circumstances where the Crown is opening up new shale gas areas. The two cases discussed below are particularly noteworthy. In both cases, the Aboriginal litigant argued that the Crown failed, at the early disposition stage, to consider the long-term scenario of fracking - that is, once the strategic decision is made to sell the lands for the ultimate purpose of oil and gas production, the Crown has little motivation to consult over long-term implications of fracking on those lands. 


\section{DENE THA' FIRST NATION V. BRITISH COLUMBIA \\ (MINISTER OF ENERGY AND MINES) ${ }^{55}$}

In Dene Tha', the Dene Tha' First Nation (DTFN) applied to the British Columbia Supreme Court for judicial review of the Ministry of Energy and Mines' decision in 2011 to dispose of certain oil and gas leases and surface tenures in the Cordova Embayment of northeastern British Columbia to Nexen, Penn West, and Vero Energy.

The central issue in this case concerned whether the Crown should have consulted with the DTFN over the sale of land per se, or whether the Crown should have consulted more broadly about the long-term, cumulative effects of fracking on the subject lands, including risks to the exercise of its Treaty 8 rights. ${ }^{56}$ The DTFN argued that a build-out scenario of Cordova development and cumulative effects on Treaty 8 rights should be the basis of consultations. ${ }^{57}$ As noted by the Court, the DTFN's central concern was that, absent early consultation over the ultimate use of fracking in this region, many approvals for infrastructure development and fracking would be a "death by a thousand cuts." 58

The Crown and Nexen argued that it was unduly speculative to assess "potential indirect, cumulative, and derivative impacts" $" 59$ at the pre-tenure stage because the necessary feasibility of conducting — and applying for - exploration and production activities had not yet been determined. ${ }^{60}$ At most, the dispositions enabled the companies to conduct preliminary and relatively non-intrusive exploration work necessary to assess if and how to exploit the resources. The Crown and Nexen argued that further practical consultations would be triggered if and when specific development applications were made.

The Court dismissed the DTFN's application, finding that the Crown correctly assessed the scope and extent of its duty to consult with the DTFN. While not discounting the "death by a thousand cuts" syndrome, the Court stated that this risk is mitigated by the fact that the Crown's assessment of shale gas development was "not a once-and-forever conclusion." 61 The Court agreed with the Crown and Nexen that the early (albeit limited) consultation was reasonable, given its ongoing nature and the future steps available to mitigate potential harm to the DTFN when exploration and development applications are filed. ${ }^{62}$

2013 BCSC 977, 51 BCLR (5th) 380 [Dene Tha'].

Ibid at paras 3-5.

Ibid (according to the DTFN, what should have been required was "consultation about ... the potential indirect, cumulative and derivative impacts to the environment and the exercise of the DTFN's treaty rights [under Treaty 8] that would flow from opening this portion of the Dene Tha's ancestral trapping grounds to the potential for shale gas development" at para 92).

Ibid at para 94 .

Ibid at para 92.

Ibid at para 93.

Ibid at para 120 .

Ibid at para 137. 
2. BUFFALO RIVER DENE NATION V.

SASKATCHEWAN (MINISTER OF ENERGY AND RESOURCES) ${ }^{63}$

While not a shale gas fracking case, Buffalo River illustrates a different judicial approach for assessing how a disposition triggers the duty to consult. In Buffalo River, the Saskatchewan Court of Appeal upheld a lower court's decision dismissing an application by the Buffalo River Dene Nation (BRDN) to judicially review decisions by Saskatchewan's Minister of Energy and Resources to post and issue Oil Sands Special Exploratory Permits. The BRDN's application focused primarily on the Minister's duty to consult with the BRDN pursuant to Treaty $10 .^{64}$

Like the DTFN in Dene Tha', the BRDN argued in part that the disposition triggered a duty to consult because it was a "strategic, higher level decision" 65 that, under Haida Nation v. British Columbia (Minister of Forests), ${ }^{66}$ triggered a duty to consult over the long-term implications. ${ }^{67}$ The Court of Queen's Bench, however, disagreed, reasoning that consideration of the duty to consult was premature, as there was no foreseeable impact on treaty rights without a subsequent approval for surface access. ${ }^{68}$

On appeal, the Court took a somewhat different approach, but came to the same result. It paid more attention to the fact that the BRDN had not advanced a claim of particular Aboriginal or treaty rights to the subject subsurface resources. ${ }^{69}$ The Court of Appeal, however, affirmed the lower court's view that the law requires more than a merely speculative impact on Aboriginal rights or claims before the duty of consultation is triggered. ${ }^{70}$ In short, this case, consistent with Dene Tha', held that an alleged breach of the duty to consult will be unsuccessful if claimants cannot demonstrate a causal relationship between the impugned government action and the potential adverse impact on treaty or Aboriginal rights.

\section{ROADBLOCKS AND CIVIL DISOBEDIENCE}

A third - and blunter - strategy to oppose fracking and industrial water use consists of roadblocks and similar forms of disobedience. Several cases in Alberta and New Brunswick highlight a fairly uniform judicial response to this strategy.

2015 SKCA 31, [2015] 7 WWR 82 [Buffalo River].

Ibid at para 1.

Ibid at para 24.

2004 SCC 73, [2004] 3 SCR 511.

Buffalo River, supra note 63 at para 24.

Buffalo River Dene Nation v Saskatchewan (Minister of Energy and Resources) et al, 2014 SKQB 69, 440 Sask R 1.

For further commentary, see Nigel Bankes, "Crown Oil Sands Dispositions and the Duty to Consult" (8 April 2015) ABlawg (blog), online: <ablawg.ca/2015/04/08/crown-oil-sands-dispositions-and-theduty-to-consult-2>.

Buffalo River, supra note 63 at paras 102-103. 


\section{LUBICON LAKE INDIAN NATION V. PENN WEST PETROLEUM LTD. ${ }^{71}$}

On 26 November 2013, protesters from the Lubicon Lake Nation (LLN), who claimed to be affiliated with Bernard Ominayak, former Chief of the LLN, began blocking access to a fracking site on their traditional territory. The blockade was located in the Sawn and Haig Lake areas of northern Alberta. Members of the LLN argued that, as their nation has never entered into a treaty with Canada containing land surrender clauses, any permits for oil and gas development on LLN land were therefore void.

On 16 December 2013, the Alberta Court of Queen's Bench granted Penn West a longterm Order prohibiting several members of the LLN from continuing to blockade a permitted access road and authorizing the police to remove the blockade and to arrest any person acting in contravention of the Order. ${ }^{72}$ The Court issued the six-month injunction pursuant to its authority under the Public Lands Act. ${ }^{73}$ The Court relied in part on the Supreme Court of Canada's decision in Behn v. Moulton Contracting Ltd.,${ }^{74}$ holding that condoning self-help remedies may be seen as bringing the administration of justice into disrepute. The Order was in force until 14 June 2014. On 3 January 2014, the LLN appealed the Order to the Court of Appeal, but has since discontinued the appeal. ${ }^{75}$

Proposals to frack New Brunswick shale gas resources have generated heated opposition. One target of this opposition is a 2012 exploration licence granted to Southwestern Energy Company (SEC). Civil disobedience opposing the SEC licence first started in September 2013, when protesters blockaded the licensee's equipment compound. The compound is located within the traditional territory of the Mi'kmaq of Elsipogtog, who are concerned about the possible long-term effects fracking might have on water resources and the ecosystem.

The protests escalated on 1 October 2013, when approximately 200 Aboriginal and other protesters created significant obstacles, preventing employees from entering and exiting the

712015 ABQB 342, [2015] 3 CNLR 156.

$72 \quad$ Ibid. See also E Bruce Mellett \& Laura Gill, "Alberta Court Grants Order Under Public Lands Act Halting Lubicon Blockade” (16 January 2014) Bennett Jones Thought Network (blog), online: Bennett Jones LLP < blog.bennettjones.com/2014/01/16/alberta-court-grants-order-under-public-lands-act-halting -lubicon-blockade>.

73 RSA 2000, c P-40. A court has broad discretionary power to make a short-term (seven days) or longterm (exceeding seven days but less than one year) order to prohibit any activity that constitutes a contravention of the Public Lands Act and to authorize the police to remove or seize any material, barrier, equipment, vehicle, structure, or obstruction used in the contravention: see ibid, ss 54.01(2)(d), 54.01(3), 54.03 (collectively these sections prohibit activities that prevent a person from gaining access to a closed road or from having free access to, passage on or over or use of a highway, road or trail). See also Mellet \& Gill, ibid.

742013 SCC 26, [2013] 2 SCR 227.

75 Lubicon Lake Nation, "Lubicon Lake Nation Appeals Injunction by PennWest Petroleum Ltd: Calls Court Decision Unconstitutional" (4 January 2014), online: <www.lubiconlakenation.ca/images/ stories/lln/mediakit/PressRelease_Jan042014_LubiconLakeNationAppealsPennWestPetroleumInjun ction.pdf $>$.

76 This case is comprised of three decisions, SWN Resources Canada Inc v Claire et al, 2013 NBQB 328, 411 NBR (2d) 239 [SWN No 1] (granting an injunction); SNW Resources Canada Inc v Claire, 2013 NBQB 342, 2013 NBQB 342 (CanLII); SWN Resources Canada Inc v Claire et al, 2013 NBQB 346, 411 NBR (2d) 375 [SWN No 3]. 
exploration site. ${ }^{77}$ The employees received repeated threats, including threats of death and bodily harm. Several weeks later, protesters clashed with police when the Royal Canadian Mounted Police (RCMP) moved to enforce an injunction against the blockade. Over forty persons were arrested and six police cruisers were set on fire. ${ }^{78}$ As a response, SWN Resources (SWN, the operating subsidiary of SEC) commenced a civil action against a number of protesters. The civil action included an application for an injunction to prevent the protesters from blocking access to SWN's equipment held on private property. SWN had at that time "expended \$20 million on its New Brunswick operations."

Shortly thereafter, SWN brought an ex parte Notice of Preliminary Motion against certain protesters for an interlocutory injunction, which was granted on 4 October 2013. The injunction effectively restrained and enjoined the respondents, until a final disposition of the action, from interfering or attempting to interfere by force, threat of force, intimidation, coercion, blocking, standing, etc. with persons seeking access to the SWN staging area and storage facility. Further, the injunction sought to prevent interference with any SWN employees. The Order permitted the respondents to "voice their objections" to the operations and permitted use of "limited signage." ${ }^{\prime 80}$ The Order was set to remain in force until 12 October $2013 .^{81}$

On 21 October 2013, the Court considered whether to extend the injunction. ${ }^{82}$ The Court found it was no longer necessary, given that all the SWN vehicles and equipment had been removed from the compound, the roadway blockade had stopped, and that while some protests were continuing in various locations, there was no evidence to establish those activities were unlawful or involved SWN. ${ }^{83}$

\section{TORT Civil ACTIONS}

A civil action filed on 3 December 2007 by Jessica Ernst alleges contamination of well water and the Rosebud aquifer, which is the source of fresh potable water for Ernst's home. ${ }^{84}$ This case comprises several distinct tort arguments against various parties, namely Encana, the Energy Resources Conservation Board (ERCB, now the Alberta Energy Regulator), and Her Majesty the Queen in Right of Alberta, represented by Alberta Environment and Sustainable Resource Development (Alberta Environment).

\section{SWN No 1, ibid at para 2}

78 See Gloria Galloway \& Jane Taber, "NB protestors plan more protests after violent clash with RCMP over shale-gas project," Globe and Mail (17 October 2013), online: <www.theglobeandmail.com/news/ national/rcmp-move-in-on-first-nation-protesting-shale-gas-development/article14904344>. SWN No 1, supra note 76 at para 2 .

Ibid at para 21 .

Ibid.

SWN No 2, supra note 76 at para 12

Ibid at para 17. As part of this consideration, the Court heard a request from the province of New Brunswick to be added as a party to the proceedings. Justice Rideout described this request as "unusual" in that the matter was arguably private. Justice Rideout, however, was satisfied that there was sufficient public interest for the province of New Brunswick to be granted intervener status, given that public roadways were involved and SWN was proceeding on the basis that the province had given SWN certain rights (ibid at paras 7,9).

84 Ernst v EnCana Corp, 2013 ABQB 537, [2013] 12 WWR 738 [Ernst QB]. 


\title{
1. ERNST V. ENCANA CORP. - REgUlATORY NEGLigENCE
}

Part of the Ernst claim is that the ERCB, as a regulator, negligently gave approvals to Encana and, in doing so, breached a duty of care owed to Ernst. The ERCB applied to the Alberta Court of Queen's Bench to strike the ERCB from the Ernst regulatory negligence claim. The Court agreed. ${ }^{85}$ On 15 September 2014, the Alberta Court of Appeal dismissed Ms. Ernst's appeal. ${ }^{86}$

On appeal, the Court of Appeal found no basis for concluding that the ERCB's public duties as set out in the Energy Resources Conservation Act transform into a private duty owed to Ernst. ${ }^{87}$ There was otherwise insufficient proximity to ground a private duty. That is, Ernst failed to establish a relationship between herself and the ERCB which created a private duty outside of the statutory regime. ${ }^{88}$ Further, even if Ernst had established that the ERCB owed her a duty of care sufficient to establish a tort claim, the Court found that her claim in negligence was barred in any event by section 43 of the ERCA. ${ }^{89}$ That section states:

\begin{abstract}
No action or proceeding may be brought against the Board or a member of the Board or a person referred to in section 10 or 17(1) in respect of any act or thing done purportedly in pursuance of this Act, or any Act that the Board administers, the regulations under any of those Acts or a decision, order or direction of the Board. $^{90}$
\end{abstract}

Ernst also challenged the scope of section 43 of the ERCA with respect to her Charter claim against the ERCB. That aspect of the Court's decision is discussed below in Part II.E.

\section{ERNST V. ENCANA CORP. ${ }^{91}$ - REGULATORY NEGLIGENCE}

Ernst also claimed that Alberta Environment negligently performed studies respecting the risks of fracking and the impacts to her well and the Rosebud aquifer. ${ }^{92}$

Ernst argued that "a government can owe a private duty of care in some circumstances" and that "there are many circumstances where courts have found governments to owe a private duty of care to an individual, even where public duties are also owed." ${ }^{93}$ Ernst submitted that her case is analogous to "cases alleging negligent investigation or negligent inspection by government actors or public authorities." 94 Alberta Environment argued that Ernst, had no reasonable claim against it because Alberta does not owe a private duty of care

2014 ABCA 285, [2014] 11 WWR 496 [Ernst CA], leave to appeal to SCC granted, 36167 (30 April 2015) [Ernst SCC].

Ernst CA, ibid at para 9, citing Energy Resources Conservation Act, RSA 2000, c E-10, s 43 [ERCA]. Ibid at para 16 .

Ibid at para 22 .

ERCA, supra note $87, \mathrm{~s} 43$.

2014 ABQB 672, [2015] 1 WWR 719 [Ernst Environment].

Ibid at paras $1-3$.

Ibid at para 33 .

Ibid at para 39. 
to Ernst, and Alberta has statutory immunity under section 220 of the Environmental Protection and Enhancement Act ${ }^{95}$ and section 157 of the Water Act. ${ }^{96}$

In 2014, Alberta Environment applied to the Alberta Court of Queen's Bench to strike this claim. The Court dismissed the government's application to strike it from the lawsuit.

In Ernst Environment, Chief Justice Wittmann of the Court of Queen's Bench dismissed Alberta's application to strike all the paragraphs of Ernst's statement of claim containing allegations against Alberta. ${ }^{97}$ The Court held, without determining the matter, that there is a reasonable prospect that Ernst will succeed in establishing that Alberta owed her a prima facie duty of care. ${ }^{98}$ The Court held that the immunity clauses in the above-noted statutes do not extend to any actions or proceedings brought against Alberta. ${ }^{99}$ The Court found that, in the alternative, the statutory immunity clauses only provide Alberta with protection for actions taken in good faith and do not extend to Ernst's allegations that Alberta acted in bad faith. ${ }^{100}$ Alberta Environment did not appeal the Court's decision. ${ }^{101}$

\section{ERNST V. ENCANA CORP ${ }^{102}$ - TORT LIABILITY}

Ernst claims that Encana contaminated her well water and the Rosebud aquifer through the company's use of fracking fluids from 2001 to 2006. Ernst's claim against Encana is based on negligence, nuisance, the rule in Rylands $v$. Fletcher, and trespass. ${ }^{103}$

If successful, the Ernst claim against Encana would be a precedent not only in Canada but in the US as well. US commentators note that, to date, there has been no reported case finding a fracking defendant liable in tort for contamination of groundwater. ${ }^{104}$ This is not to suggest US courts might not reach such a conclusion in the more than 100 analogous cases making their way through the court systems there or that such claims may not have been confidentially settled out of court.

At this stage of the Ernst litigation against Encana, it is possible to identify several potential obstacles and opportunities for plaintiffs such as Ernst. These obstacles and opportunities vary by cause of action, as discussed below.

RSA 2000, c E-12, s 220.

RSA 2000, c W-3, s 157. See Ernst Environment, supra note 91 at paras 52-61.

Ibid at para 97.

Ibid at para 94.

Ibid.

Ibid.

See Canadian Press, "Jessica Ernst legal battle: Alberta will not appeal ruling," Beacon Energy News (9 December 2014), online: < beaconenergynews.ca/energy-news/jessica-ernst-legal-battle-alberta-willnot-appeal-ruling $>$.

Ernst Environment, supra note 91.

Ibid at para 1; Rylands $v$ Fletcher (1868), LR 3 HL 330

Barclay R Nicholson, "Analysis of Litigation Involving Shale \& Hydraulic Fracturing,” Norton Rose Fulbright (1 January 2014) at 2, online: <www.nortonrosefulbright.com/files/20130723-analysis-oflitigation-involving-shale-hydraulic-fracturing-104256.pdf $>$. 
a. Trespass

The following considerations will likely be relevant regarding the trespass portion of the Ernst claim:

- The common law of trespass will be attractive to plaintiffs whose surface property rights have been impacted by the migration of fracturing fluids, saline water, and other emissions from fracking operations. It is plausible that plaintiffs such as Ernst would likely have little difficulty in proving a key threshold condition of trespass law, namely that they enjoy exclusive possession to the impacted surface lands.

- It may be a different matter for groundwater contamination. Plaintiffs would likely have more difficulty in proving the precondition of trespass that they have exclusive rights to impacted groundwater. A key unresolved question in many pending US groundwater cases is whether fee simple ownership of the surface impliedly includes exclusive possession of groundwater. The answer to this question in the US appears to depend in part on applicable state water law, as groundwater ownership varies substantially from state to state. ${ }^{105}$ In contrast, a more uniform rule of government ownership of groundwater is found in Canada. As a result, Canadian plaintiffs relying on trespass, including Ernst, may find it difficult to show that their surface fee simple rights impliedly include "exclusive" rights to the groundwater. ${ }^{106}$

b. Nuisance

As for the nuisance portion of the Ernst case, the following considerations are relevant:

- Unlike trespass law, plaintiffs using nuisance law are not required to prove "exclusive possession." The judicial focus in nuisance is whether the defendant's actions amount to an unreasonable interference with the use, not necessarily the ownership, of land. Nuisance remedies are therefore available to a wider range of plaintiffs than is the case for trespass. The Alberta Court of Appeal decision in Ball v. Imperial Oil Resources Ltd., which involved pipeline contamination, highlights how nuisance law could be successfully used by plaintiffs. ${ }^{107}$ Ms. Ball was an Alberta rancher whose cattle, located on land she leased from the province, became sick after being exposed to contaminated water and soil.

- The law of nuisance, however, is not a panacea for all persons aggrieved about fracking. Under nuisance law (unlike trespass), a court would likely assess whether fracking damages were foreseeable and whether they caused inconvenience beyond what local residents, given local land uses, can be expected to bear — that is, it may depend on which parts of the Horn and Montney areas are the subject of the Governance in the US: Summary of Initial Survey Results,” (Tuscon: University of Arizona, May 2013.

106 Moreover, these plaintiffs might not be able to rely on government groundwater withdrawal approvals to support a case in trespass - these approvals are characterized by the common law as "bare (or mere) licences" which would likely not confer exclusivity to an aquifer. 
nuisance claim. ${ }^{108}$ Moreover, nuisance plaintiffs generally, at least in Canada, now face a higher evidentiary burden after the recent Ontario Court of Appeal decision in Smith v. Inco Limited. ${ }^{109}$ The Court held that plaintiffs must prove that the industrial emissions caused actual and direct damage to their lands, as opposed to merely altered environmental conditions. ${ }^{110}$ To use the example of the Montney rancher or Ernst, these plaintiffs would be required to prove that fracking changed not only water quality or ambient noise levels, but caused actual damage (for example, loss of cattle).

\section{c. Strict Liability}

Persons aggrieved by fracking in both the US and Canada may find the tort of strict liability (known more commonly in Canada as the rule in Rylands v. Fletcher) attractive because it places a high standard of care on parties who bring "ultra-hazardous," or "nonnatural," materials to their property or conduct such activities on their property. ${ }^{111}$ Many US cases are based on strict liability, ${ }^{112}$ and determination of these pending cases will likely provide guidance on whether the use of fracking fluids, fracking of subsurface formations, extraction of water, and injection of waste water constitute "ultra-hazardous" or "nonnatural" use of lands. This tort is similar, if not identical, in Canada and the US (and features prominently in the Ernst case). ${ }^{113}$

\section{d. Negligence}

The Ernst negligence claim is framed similarity to how US litigants apply this tort. A common allegation in US litigation is that the defendant should have reasonably foreseen that its negligent fracking operation would cause harm — that is, the defendant owed a duty of care to local plaintiff residents independent of compliance with any statutory requirement. ${ }^{114}$ Such a finding would not be novel in Canada. For example, the Alberta Court of Appeal decision in Blatz v. Impact Energy Inc. et al., while not a fracking case per se, illustrates how the negligent release of contaminants from a gas well resulted in a substantial damages award for plaintiff neighbours. ${ }^{115}$

It follows that an occasional recreational user of Crown land in the Horn River Basin industrialized shale development area may have a weaker claim against fracking activity than, say, a rancher in certain parts of the Montney area where agriculture has been, despite more recent oil and gas activity, the dominant land use.

2011 ONCA 628, 340 DLR (4th) 602, leave to appeal to SCC refused, 34561 (26 April 2012). Despite several attempts to appeal the Ontario Court of Appeal decision, the Supreme Court of Canada refused to grant leave to appeal.

Ibid at para 55.

See ibid at paras $75-104$

Nicholson, supra note 104.

In the US, the tort of Rylands v Fletcher is referred to as "strict liability" - both causes of action address and provide remedies respecting damages attributed to ultra-hazardous and non-natural use of lands.

114 Nicholson, supra note 104.

1152011 ABCA 92, 502 AR 167. 


\section{e. Statutory Causes of Action}

Various US states have enacted statutory causes of action which can be used to supplement a plaintiff's common law remedies. The advantage to plaintiffs in these US statutory causes of action is that they generally lower the onus to prove causation - that is, merely being an "owner or operator" of the source of contamination could create significant liability exposure. This approach is especially popular with plaintiffs in Pennsylvania, who use that state's statutory cause of action to sue fracking operators.

Generally, Canadian legislation — including that in Alberta - does not provide such statutory causes of action. The notable exception is British Columbia's statutory cause of action respecting contaminated soil and groundwater, which appears to mirror US statutory causes of action and which could (given the broad legislative definition of "contaminants") apply to fracking fluids, saline water, and other emissions. ${ }^{116}$

\section{E. The Ernst Charter Case}

Aside from the above-noted tort claims, Ernst alleged that the ERCB breached her rights under section 2(b) of the Charter "because the ERCB barred her from communicating with them though the usual public communication channels." ${ }^{117}$ Ms. Ernst alleged that as a result she was unable to adequately communicate her concern that the Rosebud aquifer was contaminated. ${ }^{118}$ She sought damages as a personal remedy for the alleged Charter breach.

The ERCB successfully applied to the strike these allegations in Ernst QB. ${ }^{119}$ Chief Justice Wittmann found that section 43 of the ERCA acts as an absolute bar to Ernst's claims against the ERCB. ${ }^{120}$ He stated that, "if parties seeking damages could circumvent a statutory immunity clause by alleging a Charter breach, such a breach would be alleged in litigation against the government wherever possible." ${ }^{121}$ This interpretation would "lessen considerably the effectiveness of such statutory immunity clauses, and would undermine the ability of the Legislature or Parliament to balance public and private interests." "122 However, Chief Justice Wittmann clarified that, if Ernst seeks as a remedy a declaration striking down section 43 of the ERCA itself, a Notice of Constitutional Question should be given to the Attorneys General of Alberta and Canada pursuant to the Judicature Act. ${ }^{123}$

This decision was upheld on appeal. ${ }^{124}$ The Court of Appeal reasoned that, when determining whether a Charter remedy is "appropriate and just in the circumstances" pursuant to section 24(1) of the Charter, courts take traditional limits on remedies into account. ${ }^{125}$ Similarly, "the legislatures have a legitimate role in setting broad parameters

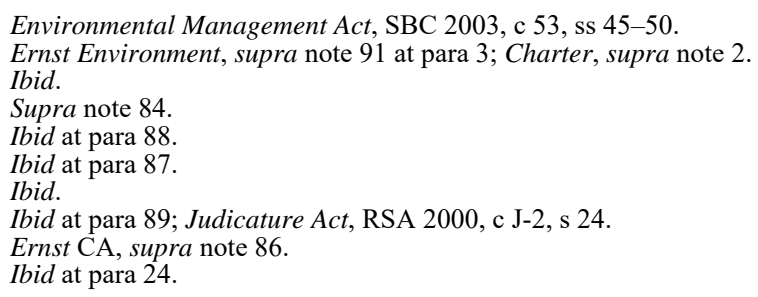


regarding available remedies." 126 As with legislatively defined limitation periods, the Court concluded there is nothing constitutionally illegitimate about statutory provisions that shield administrative decision-makers from liability, including in cases where a plaintiff seeks damages for an alleged Charter breach. ${ }^{127}$

The Supreme Court of Canada has since granted leave to appeal this decision. ${ }^{128}$ The appeal is limited to Ms. Ernst's Charter claim against the ERCB as she did not seek leave to appeal the other aspects of the Court of Appeal's decision.

\section{F. Prosecutions}

\section{R. V. NEXEN - WATER ACT PROSECUTION}

Another potential form of litigation in the fracking context is a prosecution brought against a company for committing an offence. While one Canadian case does not suggest a pattern, the current prosecution against Nexen for withdrawing water does illustrate how government can turn to the courts to enforce rules. In March 2015, the British Columbia Crown filed two charges against Nexen ULC under section 93 of the Water Act in relation to Nexen's water withdrawals in the summer of 2012. ${ }^{129}$ The subject waters were intended for Nexen's nearby fracking operations. It is too early to determine when the matter will be heard.

\section{FUTURE DiRECTION OF WATER-RELATED LitigATION}

The Canadian litigation relating to challenges of water use in the oil and gas sector is at an early formative stage, but it is possible to identify several factors that could inform future litigation strategies.

\section{A. INFLUENCE OF TSILHQOT'IN NATION V. BRITISH COLUMBIA}

In Tsilhqot'in, the Supreme Court of Canada granted a declaration recognizing the Tsilhqot'in First Nation's Aboriginal title over a portion of their traditional territory. Tsilhqot'in clarified the test for Aboriginal title and also confirmed that provincial laws continue to apply once Aboriginal title is established. ${ }^{131}$ The decision is having widespread influence on the strategies of Aboriginal groups across Canada in many different contexts and it is reasonable to conclude that Tsilhqot'in will inform challenges to fracking and other forms of water use in the oil and gas industry.

Ibid at para 28 [citations omitted]. Ibid at para 30 .

Ernst SCC, supra note 86. According to the Supreme Court of Canada docket (as of 29 September 2015), the tentative date for the hearing is 12 January 2016.

$R v$ Nexen Energy ULC (13 April 2015), Fort Nelson 5751: 11680-1, (BC Prov Ct). The Crown and Nexen Energy ULC filed a joint submission with the Court regarding disposition and sentencing, and the Court gave oral reasons for judgment on 25 November 2015 (written decision still pending). 2014 SCC 44, [2014] 2 SCR 257 [Tsilhqot'in].

Ibid at para 105 . 
News reports and early post-Tsilhqot'in litigation suggest the following possible strategies:

- Aboriginal Resource Laws: Aboriginal groups with territories in areas slated for possible fracking operations may rely on Tsilhqot'in to assert ownership of surface lands (albeit absent proof of Aboriginal title) and on that basis, require compliance with their own resource laws. As an example, the Kaska Nation, comprising five groups (Ross River Dena Council, Liard First Nation, Daylu Dena Council, Dease River First Nation and Kwadacha First Nation) asserts that their unceded traditional territories extend over parts of northern British Columbia, southeastern Yukon, and southwestern portions of the Northwest Territories. A large part of this territory includes shale gas resources, which are the subject of significant industry interest and presumably would be subject to fracking. On 27 January 2015, the Kaska Nation announced its intentions to enact resource laws binding on resource proponents. The Leaders indicated that the Kaska Resource Law will be developed within six months with passage planned at a special Kaska General Assembly to be held in summer 2015. The regulations pursuant to the laws will be developed over the next two years. ${ }^{132}$ Reflecting Tsilhqot'in, the underlying premise of the resource law initiative is requiring Kaska Nation's consent to develop resources in the territory. It remains to be seen if and when the resource laws will be adopted. ${ }^{133}$

- Aboriginal Ownership of Minerals: This argument might be asserted in both treaty and non-treaty areas. In non-treaty areas, Aboriginal groups may assert or attempt to prove ownership of oil and gas rights. Aboriginal groups may also rely on the following statement in Delgamuukw v. British Columbia, referenced in Tsilhqot'in: "[A]boriginal title also encompass mineral rights, and lands held pursuant to aboriginal title should be capable of exploitation in the same way, which is certainly not a traditional use for those lands." ${ }^{\prime 34}$ As for treaty areas, Aboriginal groups may seek to argue that treaty surrender claims should be construed narrowly to apply only to surface rights (as the focus of these treaties were rights to hunt, fish, and trap).

- Aboriginal Ownership of Water: The Tsilhqot'in claim did not address the issue of whether Aboriginal title applies to private lands, lakes, streams, or other bodies of water within the traditional territory claimed, nor does the decision address any alleged ownership of the water resource itself. Assertions of Aboriginal title to

Kaska Dena Council, Media Release, "Kaska Leaders Issue Declaration on Development of a Kaska Resource Law" (27 January 2015), online: Kaska Dena Council <www.kaskadenacouncil.com/news archives/current-news/item/kaska-leaders-issue-declaration-on-development-of-a-kaska-resource-lawmedia-release>.

133 Analogous post-Tsilhqot'in initiatives include: Tsilhqot'in National Government, Mining Policy (30 July 2014), online: Tsilhqot'in Nation <www.tsilhqotin.ca/PDFs/MiningPolicyDistribution.pdf>; Northern Secwepemc te Qelmucw Leadership Council, Northern Secwepemc te Qelmucw Nation Mining Policy (19 November 2014), online: Northern Shuswap Tribal Council <northernshuswaptribalcouncil.com/ $\mathrm{cms} /$ ? wpdmdl=1020>.

134 Tsilhqot'in, supra note 130 at para 15, citing Delgamuukw v British Columbia, [1997] 3 SCR 1010 at para 122. 
water resources may become another avenue for those challenging the oil and gas sector's use of water.

\section{B. Cumulative Effects - The Blueberry Civil ACtion}

A dominant issue in Canadian litigation concerns the cumulative effects of fracking (as discussed above in Parts II.A and II.B). This issue will likely receive more attention going forward. The Blueberry River First Nation's (BRFN) strategy for dealing with cumulative effects is through a civil action seeking damages for cumulative effects on treaty rights in northeastern British Columbia. ${ }^{135}$ The BRFN's territory is located in British Columbia's Montney shale gas play. The First Nation asserts that cumulative industrial development in its territory deprives it from exercising its Treaty 8 rights. ${ }^{136}$ The "cumulative impacts" relate to, among other things, wells, roads, pipelines, mines, clear cuts, and hydro and seismic lines. ${ }^{137}$ The BRFN also seeks an interim injunction to restrain the government from permitting further development in the area. ${ }^{138}$ This case is unique, and could create new law, for at least several reasons. While early in the process, a court will need to determine:

- whether the First Nation has standing to bring a trespass claim;

- given tort law's strong onus on plaintiffs to prove causation, whether a cumulative effect — as opposed to a single project or decision — caused the damage;

- whether failed consultation by itself amounts to a new tort;

- whether the Crown's Treaty right to "take up lands" will serve as a defence to the claim; and

- valuation of damages for lost traditional ways of life.

\section{The Water Sustainability Act (British Columbia)}

Numerous changes are contemplated in British Columbia's new WSA, ${ }^{139}$ many of which will have direct implications for the oil and gas industry. From a litigation perspective, there are more "appealable decisions" that can be revisited in a de novo EAB process. These allow for a high degree of scrutiny (more than what is evident at first instance) and can result in long reserved decisions. With the WSA's more prescriptive approach comes more formal appealable decisions. Since the WSA extends its coverage to groundwater, licenses and shortterm (two-year) use approvals for groundwater will be necessary for industrial uses. ${ }^{140} \mathrm{As}$ well, the WSA requires that notice be given to broader categories of persons, who can then

Blueberry River First Nation v British Columbia (3 March 2015), Vancouver, BCSC S-151727 (Statement of Claim), online: Ratcliff \& Co LLP < www.ratcliff.com/sites/default/files/news articles/ 2015-03-03\%20Notice\%20of\%20Civil\%20Claim.PDF>.

Ibid at 2.

Ibid at 6 .

Ibid at 9 .

Supra note 15.

Ibid, ss 48-63. 
object to licences at first instance (and then on appeal to the EAB). ${ }^{141}$ There are more substantive requirements as well, such as requirements that decision-makers consider the volume and timing of water flow required for healthy aquatic ecosystems when making water allocation decisions and a new provision about mitigating harms to streams. ${ }^{142}$

\title{
D. US CASE LAW
}

Several commentators on US litigation note the following key litigation issues to be determined by US courts which may be particularly relevant in Canadian litigation:

- Pending Litigation: One commentator described the current state of litigation in the US as follows:

\begin{abstract}
While lawmakers debate the need for policies and regulations, and environmental agencies prepare studies and conduct tests, the number of civil cases involving hydraulic fracturing is rising. Many of these lawsuits (some of which are class actions) that have been filed by landowners in Arkansas, Colorado, Louisiana, Ohio, New York, Pennsylvania, Texas, and West Virginia against oil and gas operating and drilling companies, allege contamination of groundwater or sources of drinking water. These landowners either leased oil and gas rights to the companies, or reside in close proximity to where hydraulic fracturing operations have been conducted. Other shale and hydraulic fracturing lawsuits concern earthquakes, environmental issues, regulatory enforcement, municipal bans, government regulations, and oil and gas lease disputes.
\end{abstract}

Many of the cases are in the early stages of litigation, while others have been dismissed or settled. As of the date of this White Paper, the authors have not located any judgment against a well operator, drilling contractor, or service company for contamination of groundwater resulting from hydraulic fracturing. ${ }^{143}$

- Causation: This appears to be a dominant issue in US litigation. One commentator noted as follows:

Landowner suits are typically based on a claim that fracking activities contaminated property and groundwater resources with methane gas, metals, benzene or other contaminants, and exposed the occupants to hazardous substances. 
As the body of case law matures...causation will be the linchpin to withstanding dispositive motions and ultimately reaching a jury. In the meanwhile, about half of the cases filed have been resolved by settlement, voluntary withdrawal, and motions to dismiss.

\begin{abstract}
A number of cases allege that fracking is an abnormally dangerous activity which subjects defendants to strict liability. Strict liability reduces a plaintiff's burden to proving only causation and damages. Typically, it is not necessary to show that the defendant had a duty of care that was breached. An abnormally dangerous activity is one that is shown to pose a high risk of significant harm to people or property, which harm cannot be reduced through reasonable care, is generally uncommon and inappropriate for the area where carried out, and in which the risk of harm outweighs the benefits to the community. As yet, no published ruling has held fracking to be an abnormally dangerous activity but cases are pending that have withstood early motions to dismiss. $^{144}$
\end{abstract}

A potential causation case was recently rendered in Texas and is the first of what is expected to be a number of such decisions as there are many pending cases. ${ }^{145}$ In that case, a Dallas jury awarded \$2.9 million to plaintiff landowners who alleged that local fracking and drilling activities exposed them to hazardous gases, chemicals, and industrial waste, and caused substantial diminution of property value. ${ }^{146}$ The defendant operator has appealed the decision, largely on grounds that the trial court failed to adequately consider that the subject fracking and drilling activities were but a small portion of the heavy oil and gas activity in that area and that the plaintiffs had not proven on a balance on probabilities that the defendant's operations caused the damage (both key elements for a private nuisance claim). Unique to US litigation and not found in Canada (at least not yet) is the Lone Pine $e^{147}$ evidentiary rule:

One strategy that fracking litigation defendants have attempted to use to curtail speculative, unsubstantiated claims of property contamination and exposure, and to reduce litigation costs, is to seek the so-called Lone

William J Jackson \& Lori Warner, "Hydraulic Fracturing Litigation Case Law Update: Recent Rulings in Pending Tort Litigation" (Paper delivered at the American Bar Association Section of Environment, Energy, and Resources 21st Section Fall Meeting, Baltimore, MD, 9-12 October 2013) at 2-7, online: Jackson, Gilmour \& Dobbs < www.jgdpc.com/Hydraulic-Fracking-Litigation-Survey-Paper-for-ABASEER-Section-Fall-Meeting-2013.pdf $>$ [citation omitted].

Parr v Aruba Petroleum Inc, Cause No CC-11-01650-E, (Tex County Ct at Law 2014); now under appeal (see Aruba Petroleum Inc v Parr, No 05-14-01285-CV (Tex App)).

Mark Rodriguez \& Brock Skelley, "Fracking Litigation to Watch in 2015," Texas Lawyer (19 January 2015), online: <www.texaslawyer.com/id=1202715260010/Fracking-Litigation-to-Watch-in-2015>. The plaintiff Parr originally filed eight tort causes of action, but after years of legal motions and rulings, the judge directed the jury to consider a single cause of action, namely that of private nuisance: see Court's jury charge respecting private nuisance at "Jury Charge," Cause No 11-01650-F, filed 22 April 2014, online: Beveridge \& Diamond <www.bdlaw.com/assets/htmldocuments/Parr\%20Verdict.pdf>. Lore v Lone Pine Corp, 1986 WL 637507 (NJ Sup Ct). 
Pine order. Lone Pine orders derive from Lore v Lone Pine Corp., a toxic tort case against a landfill operator and hundreds of parties who sent or hauled materials to the site. In that case, soon after suit was filed, the court ordered the plaintiffs to submit evidence of each plaintiff's exposure to the alleged toxic substances, and to provide expert opinions supporting causation. The order required the plaintiffs to make a prima facie showing of the alleged personal injury and property damage claims, including causation, before the court would proceed with what would be complex, prolonged and expensive litigation. The case was dismissed after the Lone Pine plaintiffs were unable establish a sufficient basis to continue the litigation. ${ }^{148}$

\section{CONCLuSions}

As the cases discussed above illustrate, those opposed to fracking and other water-related developments in the oil and gas industry are employing highly diverse strategies to challenge these activities. It is difficult to conclude that any one strategy is most effective. Indeed, in the cases that have been determined, for example the blockade injunctions, and the attempts to challenge mineral dispositions and permits at the exploratory phase, the challenges have all failed.

At this stage, however, it is premature to conclude that challenges to water-related oil and gas developments are futile. A key decision is FNFN v. British Columbia, ${ }^{149}$ as the hearing canvassed a number of issues that will likely arise in future cases. As well, the ultimate outcome of $R v$. Nexen may foreshadow new policy directions; the EAB certainly provided a long agenda for future consideration. In the civil law sphere, the developing body of US law will likely inform the Canadian context, at least in the Ernst v. Encana example (as discussed above in Part II.D). Challenges based on Aboriginal and Treaty rights will be another area to watch, particularly since Aboriginal groups appear to have more leverage post-Tsilhqot'in. It remains to be seen which strategy, if any, will prevail. 
this page is blank - do not strip it in 